\title{
OVERCOMING POLARIZATION
}

\author{
Jennifer McCoy and Murat Somer
}

Forthcoming in Journal of Democracy, January 2021

\begin{abstract}
Jennifer McCoy is Distinguished University Professor in political science at Georgia State University. Murat Somer is professor of political science and international relations at Koç University in Istanbul.
\end{abstract}

\begin{abstract}
Around the world, democracy is being undermined by elected leaders using polarizing political strategies that divide societies into mutually distrustful camps. The logic of polarization creates incentives for political leaders and voters to sacrifice democratic principles rather than risk losing power, and it changes the capacity of institutions designed to manage political conflict and sustain democracy. Drawing lessons from comparative experiences around the world, we propose strategies for oppositions to depolarize or repolarize around democracy-building agendas. We further analyze the challenges of "the day after" polarizing incumbents are removed and how strategic choices to emphasize long-term collective interests over short-term partisan interests can begin to shift the vicious cycle to a virtuous one.
\end{abstract}

Whether intentionally or not, elected officials around the world are subverting democracy from within by using polarizing political strategies in their bids to gain or retain power. Their societies are left to grapple with a vexing challenge: pernicious polarization. We argue that polarization is a process of simplifying politics by presenting either-or choices to the public, thus consolidating the political field into opposing, increasingly immovable blocs. It becomes pernicious, or harmful for democracy, when it divides the electorate into two mutually distrustful camps. ${ }^{1}$ Such conditions can trap societies in a vicious cycle of polarizing strategies and democratic erosion, and the choices of political actors are key to finding a way out.

In some cases, polarization stresses but does not necessarily degrade democracy—at least not right away. One example of such strain on a still-functioning democracy might be the United Kingdom, where new divides over Brexit — fed by the political strategies of the Conservative and 
U.K. Independence Parties - led to three years of government paralysis and dysfunction. The long-term effects remain to be seen, as these developments have weakened longstanding democratic norms. ${ }^{2}$

Polarization can also be generated by leaders or parties seeking to concentrate power, as we have seen in Hungary and Turkey. Once elected, new governments deployed divisive rhetoric along with bold initiatives to enhance executive power by reengineering electoral systems, civil society, and constitutions; to undermine democratic freedoms and procedures; and to entrench their party's advantage in future elections. Through these tactics of creeping authoritarianism, they transformed their democracies into competitive authoritarian regimes. ${ }^{3}$ In yet other examples, competitive authoritarian parties double down on polarizing politics to regain power after losing elections. The Barisan Nasional (National Front) and its core party UMNO, which had dominated Malaysia for sixty years, lost to the opposition coalition Pakatan Harapan (Alliance of Hope) in a 2018 election. In 2020, Barisan Nasional won back its dominant position by repolarizing society along ethnonationalist and religious lines that overshadowed the opposition's democratic-reform agenda. ${ }^{4}$

Perhaps the most damaging to democracy are cases in which a leader incorporates a previously marginalized sector into power and meets with a backlash from displaced elites or formerly dominant groups. In some cases, the new incumbent uses polarizing politics, and hostile political and institutional actors respond by removing the elected government via extraconstitutional court decisions or military intervention. In Thailand, for instance, military and conservative forces dislodged successive elected governments led by populist Thaksin Shinawatra and his supporters until a definitive 2014 coup from which Thai democracy has still not recovered. ${ }^{5}$ In other cases, polarizing reactions occur because leaders or parties representing 
new social groups are perceived as threatening due to their identities or ideologies. For example, the presidential-election victory of Luiz Inácio Lula da Silva, leader of the Workers’ Party, initially generated a new sentiment of dislike between supporters of the opposing parties in Brazil, and the election of Barack Obama, the first African-American president, triggered a polarizing backlash in the United States. ${ }^{6}$

Finally, democratic oppositions that succeed polarizing authoritarian leaders in office may fail to reverse the downward spiral if they opt for score-settling, punishing former incumbents. In South Korea, for example, former prodemocracy activists helped to impeach and then replace a polarizing and democracy-eroding president, Park Geun-hye. Once they won control of both the presidency and the National Assembly, however, Park's opponents began to indulge in economic populism, moralistic revanchism, and democracy-eroding practices themselves, instead of bringing the country together in search of long-term solutions to structural inequalities. ${ }^{7}$ When oppositions thus fail to address the underlying grievances giving rise to polarization and its receptive audiences, an authoritarian polarizer may eventually be able to return to power on the back of sweeping promises to a disgruntled public.

The United States is in many ways a distinctive case of democracy, with its unusual minoritarian institutions - an indirect presidential-election system and a powerful Senate giving an advantage to less-populous states — combined with strong majoritarian features that favor a two-party system, such as single-member plurality districts at the national and state levels. Together with a longstanding constitution, informal democratic norms, a strong civil society, and a federal system, these institutional features have long been seen as sources of democratic resilience. Yet the United States has been experiencing dynamics of pernicious polarization and the consequent erosion in democratic quality that resemble patterns seen in some less established 
democracies, underscored by a drop in its Freedom House political-rights score and downgrade to the category of "flawed democracy" by the Economist Intelligence Unit.

The puzzle we address is how a normal democratic practice used to win competitive elections - mobilizing support by simplifying the agenda and sharply distinguishing a candidate or party from the opposition-can at the same time threaten democracy. We argue that the process of polarization, if not contained or channeled through an explicit democracy-rebuilding program, creates a vicious cycle: It changes the incentives for political actors and voters alike in ways that lead them to sacrifice democratic principles rather than risk losing power.

Shifting the logic of polarization from a vicious cycle to a virtuous one will require responding to the underlying grievances and deficiencies in representation, welfare, governance, and inclusion that made societies receptive to polarizing strategies in the first place. Here we can learn from successes and failures of countries suffering pernicious polarization, though there are no simple answers and few sustained positive examples. This is partly because democratic oppositions have not yet had time to develop strategies for coping with the novel features of the "third wave of autocratization." It is also because once they have taken on a life of their own, pernicious polarization and its associated democratic erosion are difficult to stop.

\section{Polarization: Origins and Effects}

A crucial step may be understanding the Janus-faced relationship of polarization to democracy. ${ }^{9}$ Simplifying politics by generating opposition and exclusion is part of democratic contestation. ${ }^{10}$ At some historical junctures, polarization can serve to deepen democracy, as when reformers polarize to disrupt undemocratic elements of the status quo and work for greater

social justice or democratic inclusion. Improving democracy may thus require a certain degree of 
rule-breaking and erosion of existing norms. ${ }^{11}$ Nevertheless, once activated, polarization risks becoming a self-propagating dynamic that spirals out of control.

Polarization may also result from conflicts between groups with different expectations from democracy, reflected in their views on such matters as the optimal distribution of resources, or whether democracy should take a more participatory or a more liberal form. Democratic backsliding often polarizes society between those who perceive themselves as benefiting from autocratization versus those who feel harmed. Public-opinion polls in Venezuela under Hugo Chávez showed polarization around the question of whether democracy itself was improving or deteriorating. Even in the United States, the health or integrity of democracy was a question that polarized supporters and opponents of President Trump.

Not all polarizers are autocrats, at least not from the beginning. Indeed, disruptive polarizing actors may promote democratic-reformist platforms and remain principled democrats to the end; one example would be Martin Luther King, Jr. and the U.S. civil rights movement of the 1950s and 1960s. Many other polarizers, however, whether animated by personal corruption and a thirst for power or by projects (such as racist, fascist, communist, theocratic, or extremenationalist ones) that are incompatible with liberal democracy, are opportunistic democrats. Such agents employ polarizing politics to pursue these goals within democracy, which they view as an instrument at best and a barrier at worst. This results in the undermining of democracy from within. Far-right parties and movements in Europe, for example, from Marine Le Pen's National Rally in France to the Freedom Party in Austria, seem to admire the strongman model of political leadership represented by Russia's Vladimir Putin. ${ }^{12}$

Regardless of intentions, polarizing politics transforms the actors involved and always carries with it the risk of spiraling out of control. Authoritarianism may emerge from the ways in 
which pernicious polarization changes actors' interests, perceptions, and incentives, with important implications (for instance) for political forces that emerge as broad coalitions of moderates and hardliners. Whatever one makes of the initial personal motives of Chávez in Venezuela and Recep Tayyip Erdoğan in Turkey, their movements began this way. Erdoğan's coalition included ideological authoritarians such as radical Islamists alongside principled democrats; old-style Communist intellectuals and military officials rallied behind Chávez together with theorists of participatory and communal democracy. Polarization pushes out the

compromise-minded moderates and bolsters those with more radical agendas. ${ }^{13}$ And growing perceptions of existential threat can motivate citizens and leaders alike to adopt more democracy-eroding attitudes and policies.

\section{The Logic of Polarization}

In studies of polarized countries around the world, we found that the logic of polarization produced a common set of incentives for incumbents, oppositions, institutional actors, civil society (including the media), and voters. We identified a sequence of steps, illustrated in Figure 1, that begins with a political entrepreneur exploiting popular grievances by using "us versus them" rhetoric, casting blame on alleged enemies, and fueling suspicion and distrust. These polarizing actors also draw on or invent political identities, and stories supporting these identities, that mobilize otherwise diverse constituencies. Over time, they divide electorates into opposing political camps with fewer and fewer cross-cutting ties. Politics takes on the dynamics of an intense conflict whose participants display in-group loyalty coupled with dislike and distrust of the opposing group, which they come to view as an existential threat. Simultaneously, 
political leaders wield polarization to discredit and sideline opponents or internal rivals, as well as to disrupt established rules and institutions.

Polarization is thus a political strategy for achieving particular ends, which can range from simply winning elections or dominating rival factions to fundamentally transforming society. But it is also a process that evolves through the interaction of the opposed political camps. This can eventually result in an equilibrium, in which actors become locked in the behaviors that reproduce pernicious polarization unless and until either an exogenous shock alters this condition, or actors themselves voluntarily, and courageously, change it through their actions.

In a state of perceived mutual threat and zero-sum politics, political leaders and their supporters are incentivized to use any means available to win the struggle for power. Especially when both sides are represented by institutionalized organizations such as mass political parties, neither side may be able to vanquish the other. But a vicious cycle legitimizing and incentivizing authoritarian, populist, and illiberal behavior erodes democracy, whose formal and informal norms are increasingly set aside.

Polarizing leaders often strive to transform the constitutional order, for instance in order to secure unfair electoral advantages or to skew the workings of the judiciary or similar institutions. Parties are likelier to resort to strategies of voter suppression, gerrymandering, disinformation, candidacy restrictions, and media closures in polarized contexts, insofar as polarization closes off opportunities for politicians to win by persuading opposition voters to switch sides. The remaining route to victory lies in either keeping opposition voters away from the polls or in engineering systems of disproportionate representation that favor the incumbent's camp. $^{14}$ 


\section{FIGURE HERE}

Polarization affects citizen attitudes toward democracy as well, with the result that public opinion becomes less of a check on democracy-eroding political actors. Recent research has demonstrated that in polarized contexts, the most partisan voters are the least likely to punish candidates, particularly those of their own party, for positions that violate democratic norms. ${ }^{15}$

In two 2020 studies of U.S. voters (in March and August), one of us, with coauthors, investigated whether voters practice democratic hypocrisy — that is, whether in polarized contexts they condition their support for democratic norms on whether their own party is in power. We theorized that one feature of pernicious polarization — the growing perception among both parties' supporters that the opposing party's policies pose a threat to the nation-would lead these polarized voters to tolerate or even encourage policies that erode democratic norms. ${ }^{16} \mathrm{We}$ used an experimental design to manipulate the party in power by presenting respondents with hypothetical scenarios about the outcome of the 2020 U.S. elections. In the second study, we then manipulated perceptions of the threat posed by the opposing party.

These studies produced sobering findings. First, a significant fraction of Americans encourage rather than merely tolerate policies that challenge existing democratic norms. At a time when (as in the really existing conditions of 2020) Republicans controlled the presidency, the Senate, and more than half of state governorships, while Democrats controlled the House of Representatives, the sixteen norm-challenging policies that we proposed received support from 13 to 35 percent of Democrat-identifying respondents and 16 to 65 percent of Republicanidentifying respondents (with levels of support varying depending on the individual policy). Our experiment was designed to test whether those numbers would change if respondents imagined a 
different political scenario, and we found that this was indeed the case: Citizens whose preferred party is in power are substantially more likely to support norm-changing policies. ${ }^{17}$

Although democratic hypocrisy was most pronounced with regard to respondents' approval of a proposed tactic that was not strictly unconstitutional—using executive orders to change major policy — it was also evident with regard to more egregiously democracy-eroding acts, such as allowing the president to disqualify candidates he or she considered disloyal to the country; allowing the president to prosecute journalists; and rejecting election results they believed to be unfair. Finally, we found that citizens primed to feel threatened by the opposing party want to keep things more democratic when that party is in power. When their own party is in power, by contrast, their support for norm-eroding policies rises; in fact, the democratic hypocrisy of such respondents is more than double that recorded among respondents who have not been similarly primed.

\section{Overcoming Pernicious Polarization}

How can societies overcome pernicious polarization? Based on our own research and a review of other studies, we can identify a number of lessons.

Underlying Grievances and Unresponsive Political Institutions. Populist polarizers may offer false solutions and employ democracy-eroding tactics, but they may not always be wrong in identifying problems. From Turkey to Thailand, Colombia, Venezuela, Italy, the United Kingdom, and the United States, legitimate sociocultural and political-economic grievances, together with declining public trust in the ability of democratic systems to address them, produced a demand for change that preceded the rise of polarizing politicians. While some of these problems arguably are governments' own doing, others result from demographic, 
economic, and technological changes to which publics expect their governments to respond. As grievances deepen, citizens become receptive to political entrepreneurs who spotlight or magnify these troubles. Acknowledging these governance shortfalls is a required first step toward reversing polarization. Hence, depolarizers who aspire to save democracy by restoring the status quo can postpone the problem, but are unlikely to solve it in the long run.

Polarization Changes Institutions. Polarization changes the way political institutions operate. Consensus-promoting mechanisms break down when the two camps refuse to cooperate; for example, rules requiring a legislative supermajority to approve the appointment of high-court justices can be subverted either by an opposition refusing to consider nominees or by a governing party deciding to do away with such rules. Bodies intended to ensure accountability lose their capacity to provide oversight as the government politicizes courts and anticorruption bodies by appointing its sympathizers, or casts investigative journalists or impeachment proceedings as biased or illegitimate.

Majoritarian institutions easily turn into existential threats when competitors come to see politics as a zero-sum game. For example, disproportionate representation may be built into constitutions (as in postcommunist Hungary) as a mechanism for ensuring stability and moderation, but political actors can build on these systems to enhance their advantage and even secure a permanent majority through gerrymandering or changes to electoral formulas. Although single-member-district plurality systems tend to create the greatest discrepancies between parties' respective vote shares and their representation in office, proportional-representation systems are also subject to these distortions if they include mechanisms that reward the highestperforming party with extra seats (as exist in varying forms in Turkey and in Greece). 
Minority-empowering institutions also change incentives. For example, upper houses in federal systems that allocate an equal number of seats to each state, regardless of population - as in Australia, Brazil, and Mexico - award disproportionate representation to less populous, often rural, states. The problem is that the partisan sorting often accompanying polarization may confer this advantage on one particular party over the long term. In the United States, for example, the Senate's setup (under which each state has two seats regardless of population size) has historically produced a disproportion in representation; in 2016, for instance, legislators representing 59.5 percent of the population held only 24 percent of seats in this chamber. The increasing geographic sorting of the parties has turned this discrepancy into an advantage for the Republican Party. ${ }^{18}$ Together with the institutional advantage that the Electoral College confers on low-population states, this reduces the incentives for Republicans to diversify and expand their voter base even when they command only a minority of the national popular vote. ${ }^{19}$

Even party institutionalization becomes a double-edged sword in a severely polarized context. While many political scientists consider party institutionalization to be a requirement of democratic consolidation, in settings where polarization reigns, strong parties with loyal followings merely entrench this dynamic. ${ }^{20}$ Likewise, party-system fragmentation can have variable effects in a polarized context. It may hinder the division of society into two political camps and the associated gridlock, but it may also incentivize a political entrepreneur to adopt polarizing strategies to gain power. Hence, choices made by political-party elites are crucial. Institutional changes can create new incentives for parties to reduce polarizing behavior, although potential unintended consequences need to be considered. In the United States, for instance, reforms such as eliminating the Senate filibuster could improve governability by removing the minority party's ability to obstruct all legislation in a polarized struggle. 
Encouraging states to award their electoral votes proportionally based on state-level vote totals (rather than on a winner-takes-all basis) might alter the incentives currently associated with the Electoral College.

Another way to break the disincentives of a zero-sum-game could be implementing schemes to increase choice in representation. Under ranked-choice voting, also called an "instant run-off" system, voters can indicate their first-, second-, and third-choice candidates. If no candidate obtains a majority of first preferences, the candidate with the fewest votes is eliminated and the next-choice candidates of this person's supporters get their votes, with this procedure repeated until one person finally gets a majority. This system addresses several ills associated with pernicious polarization: It encourages candidates to adopt broader and more moderate campaign messages that will appeal beyond their base to voters who might pick them as a second choice, an

$d$ it eliminates the sense that voters who support low-viability candidates outside the two main camps are "wasting" their votes. It is used nationally in Australia and Ireland, and at local levels in New Zealand, the United Kingdom, and the United States, among other jurisdictions, with high ratings from voters. ${ }^{21}$

Opposition strategies are crucial. Since democratic oppositions are still learning how to overcome the interlinked dynamics of pernicious polarization and democratic erosion, examples of successful strategies for reversing these vicious cycles are still scarce. Hence we draw on a combination of empirical and deductive theorizing to advance three main insights. ${ }^{22}$ First, as opposition parties, candidates, and supporters are drawn into the competitive dynamics of polarization, their responses often reinforce pernicious polarization and democratic erosion. Second, opposition dilemmas and internal divisions, driven by polarization, can hinder the 
adoption of successful strategies. Third, successful and unsuccessful opposition strategies can be sorted into an emerging typology: While much depends on the social, cultural, and political contexts of particular countries, oppositions face basic choices between generative or preservative goals on one hand, and between polarizing and depolarizing strategies on the other. We argue that active-depolarizing and transformative-repolarizing strategies are more promising than passive-depolarizing and reciprocal-repolarizing strategies.

Passive-depolarizing strategies that merely appeal to an existing social-political center, aiming to preserve it, bode well for deactivating polarization in the short but not the long run. More promising are active-depolarizing strategies that work to regenerate the center by putting forth new unifying issues, messages, and stories that appeal to common interests and values. Recently, candidates in Istanbul, Budapest, and Bratislava have succeeded in defeating authoritarian-populist officeholders at the polls by advancing new unifying narratives and reaching out to the incumbent's base through novel campaign methods and positive emotional appeals.

Similarly, we distinguish between reciprocal and transformative re-polarizing strategies. Reciprocal-repolarizing strategies, which reproduce the zero-sum mentality and demonizing rhetoric of the incumbent along the existing axes of polarization, usually exacerbate the vicious cycle. However, transformative repolarization around axes of democratic values and reforms that address underlying grievances can start a virtuous cycle. For instance, pressure from a social movement that sprang up around social-justice issues in Chile in 2019 changed the axis of polarization and led to a successful referendum on organizing a constituent assembly. While Malaysia's long-term trajectory remains uncertain, the Alliance of Hope's 2018 strategy of emphasizing the reform-autocracy divide succeeded in displacing a competitive authoritarian 
political force that had ruled for six decades. In Armenia's 2018 Velvet Revolution, a

prodemocratic mobilization dealt an unexpected defeat to a semiauthoritarian incumbent. ${ }^{23}$

Finding and implementing the right strategy to overcome pernicious polarization is not merely an intellectual challenge. The parties, leaders, social movements, and civil society groups that make up democratic oppositions each have their own interests and internal power struggles, and these may undermine their ability to play constructive roles—or render opposition actors themselves agents of polarization. An opposition party may even be the primary polarizing actor, adopting obstructionist strategies or playing "constitutional hardball" for its own partisan ends.

Avoid Formative Rifts. Polarization becomes especially dangerous when polarizing actors exploit formative rifts—cleavages resulting from unresolved conflicts over citizenship rights or national identity or territory that emerge during the establishment of states and that are hard to resolve without fundamentally changing how these states are configured. In Bolivia, such rifts exist over questions of indigenous rights and participation. These divisions became deeply polarizing when the country's first indigenous president Evo Morales convened a contentious constitutional-reform process, then attempted to extend his tenure for a fourth term and was ousted amid protests, ushering in a hardline conservative government that attempted to restore the prior status quo of elite domination. In Turkey, Erdoğan's strategy for concentrating power relied on polarization around formative rifts that run along the religious-secular cleavage and the divide between ethnic Kurds and ethnic Turks. In the United States, unresolved historic debates over citizenship rights for enslaved persons from Africa and their descendants have repeatedly emerged as the basis of pernicious polarization.

When formative rifts become the axis of polarization—even as part of a prodemocratic mobilization — a vicious cycle is likely to ensue. To avoid this fate, democratic systems should 
address these unresolved rifts through collective deliberation, broad-based consensus building, and incremental reforms.

The Day After Polarizing Leaders Leave Office. If oppositions are to reverse pernicious polarization and its associated democratic erosion, a sound strategy for the period after a polarizing leader has been defeated is key. Simply removing a polarizing figure or party does not end polarization. Partisan antipathy and distrust within society will remain, and heightened resentments, habits of obstruction, and perceptions of incompatible goals are likely to continue to impede cross-partisan cooperation. New leaders need to address the underlying grievances and deficiencies in representation, equity, inclusion, and fairness that gave rise to polarization in the first place.

The nature of a polarizing incumbent's departure will influence how that incumbent's supporters respond to attempts at depolarization. Was the leader in question defeated in an election perceived as free and fair, or removed through an impeachment process perceived as impartial? Or were they dislodged by extra-constitutional means or through legal processes seen as politicized $?^{24}$ In the latter case, the new government is likely to be perceived as illegitimate by a significant portion of the electorate, and consequently to have a harder time restoring trust. Treating the polarizer's supporters with dignity, avoiding denigration and revanchist behavior, and emphasizing collective values and interests are crucial if the new leadership is to avoid stoking resentment and renewed conflict. So, too, is guaranteeing the rights of the defeated movement to keep participating in politics. New governments can also broaden their coalitions by making connections with social organizations; this can contribute to active depolarization or shift the focus to addressing historic inequities or formative rifts, a positive step so long as it does not produce a new us versus them logic. 
Governments that succeed a polarizing incumbent are likely to face additional constraints. Bureaucracies and courts may be filled with allies of the previous government; the polarizer may continue to wield influence outside of government; and continued grievances may set the stage for a comeback of the defeated political force or the advent of a new polarizer. Populist Silvio Berlusconi, for instance, returned two times as Italy's prime minister after recovering from intervening electoral defeats. Although Argentine president Juan Perón was exiled and his populist party banned in 1955, Peronism not only survived but has been the governing faction in Argentina for all but six of the last thirty years.

Internal Party Renewals: Promising But No Guarantee. Internal party renewal or leadership changes can help parties to depolarize whether they are in government or in opposition at the time. Overcoming internal divisions may be difficult for the political force that succeeds a polarizing actor, particularly if this force is a coalition assembled solely to displace the polarizer. The Venezuelan opponents of Hugo Chávez and his successor Nicolas Máduro have faced this problem for two decades, including after they won a stunning two-thirds legislative majority in 2015.

Such parties or coalitions will need to seek consensus on an active depolarization strategy or a new axis for transformative repolarization. Over the long haul, parties need to renew their programs so as to offer effective solutions to the structural underpinnings of polarization. For instance, they might consider advancing new regulatory approaches covering social-media companies such as Facebook and Twitter in response to the "personal-data surveillance economy" that has made it harder for citizens to find a truth-based common ground. ${ }^{25}$ Party renewal also has an organizational dimension. Reaching out to voters across the aisle requires 
not only compelling new messages, but also party structures that can communicate effectively with the public.

Voluntary change within polarizing parties can make a major contribution, improving the political situation without need for such extreme measures as the forceful removal of leaders or bans on their movements. Such internal change is most likely to come about when polarizing incumbents bump up against term limits they are unable to circumvent, or are otherwise removed from office.

To prolong their sway, polarizing leaders in this situation may advance a successor through whom they hope to wield influence from behind the scenes. On occasion, however, such successors have surprised their benefactors by changing course to calm political rifts or even reverse past democracy-eroding policies. In Colombia, Juan Manuel Santos broke with his predecessor Álvaro Uribe to pursue peace talks with the FARC; in Ecuador, Lenín Moreno pursued corruption charges against his erstwhile patron Rafael Correa; and in Bolivia, Luis Arce won the October 2020 election for the Movement Toward Socialism (MAS) on a moderate platform after MAS founder Evo Morales was exiled. It is important to note that such reversals do not necessarily produce lasting depolarization: In the first two cases, the former leaders repolarized society through attacks on their successors, while in Bolivia it remains to be seen whether Arce can maintain his independence with Morales now back in the country. In the United States, the future influence that Donald Trump — with his sizable Twitter following and sway over many voters - will exert on the Republican party remains a question.

Political Agency. Ultimately, the prospects for saving democracy hinge on political agency — in other words, on human will and creativity — in two key regards. The first involves 
strategic choice in scenarios where long-term collective interest and short-term partisan interest come into conflict.

Not all polarizing actors are equally competent and lucky. They all appeal to their bases emotionally by telling stories that exploit real grievances, draw on half-truths, sidestep actual problems, and scapegoat real or fictional villains that range from corrupt elites to immigrants. These stories can be powerful tools for providing people with a political identity and mental justifications for partisan loyalty. ${ }^{26}$ But polarizers differ widely not only in their storytelling abilities, but in their ability to provide supporters with tangible benefits and to secure their own grip on power. This partially explains why some polarizers, such as Erdoğan in Turkey or Russia’s Vladimir Putin, are able at first repeatedly to win competitive (if not fully fair) elections while others, such as Trump, lose their reelection bids and still others, such as Venezuela's Nicolás Maduro, can remain in office only by resorting to rising repression and electoral manipulation.

Over time, facing dwindling resources or the need to resort to extra-constitutional means to get around term limits, even initially successful polarizers are likely to find themselves unable to win elections without serious manipulation. Whenever it comes, their departure does not mean that their base will immediately abandon their polarizing political positions. In the United States, the next administration will likely face distrust in the incoming government and in the electoral process among the close to half of the electorate that voted for Trump in 2020.

When populist polarizers lose an election, potentially more talented elites within their party or base face a strategic choice. They can to try mobilizing the base with similar projects, but with greater competence. If they succeed, all the democracy-eroding consequences of pernicious polarization may return with a vengeance. Alternatively, up-and-coming politicians 
can discard polarizing strategies in favor of active or passive depolarizing strategies, or they can invent new and more democracy-friendly stories to mobilize their base.

This is easier said than done, however, which brings us to the second sense in which political agency is crucial in determining the outcome for democracy. It takes political will as well as creative skills to produce democracy-friendly stories that simultaneously tap successfully into people's emotional sensitivities, replace the stories they previously embraced, and still feed a distinct political identity. All moving stories have villains and heroes. If not immigrants, China, and Washington elites, what should these stories blame for the declining faith in the American dream among disaffected white working-class voters, for example? Democracy-saving political entrepreneurs need to adopt reformist institutional, political, and economic platforms, as well as to invent powerful stories that appeal to their base's emotional core.

One approach to revising the narrative involves recognizing how identity-based appeals have replaced issue-based appeals. Right-wing parties in established democracies have been particularly adept at responding to the resentment, anger, and even humiliation resulting from the shifting labor markets produced by globalization and automation. For example, men who lose the identity or sense of self-worth that came from providing for their families economically may seek new meaning in cultural identities defined in religious, ethnic, or national terms. ${ }^{27} \mathrm{In}$ Europe and the United States, right-wing populists have exploited such grievances through exclusionary anti-immigrant and ethnonationalist appeals.

In the United States under Bill Clinton and the United Kingdom under Tony Blair, the center-left adopted "third way" narratives of rising mobility enabled by a college education. Because they failed to recognize the roles played by structural constraints, accidents of birth, and sheer luck, these narratives placed on individuals the full weight of responsibility for their own 
success or failure. ${ }^{28}$ By the 2010s, a populist message scapegoating immigrants, the Chinese, or racial minorities may thus have offered a more satisfactory explanation for many among the noncollege-educated two-thirds of the population in both countries, some of whom are also feeling a loss of status in connection with the growing diversification of their workplaces and public spaces.

A new narrative might redefine the dignity of work, using tax reforms rather than relying solely on the market to define contributions to the common good. Realigning the extraordinary, cultural-identity-based coalition that exists in the United States between the rich and the white working class, which has stymied the adoption of redistributive policies in a manner unique to the U.S. case, could begin shifting the axis of polarization in ways that would reduce its pernicious character. ${ }^{29}$

Polarization is useful to democracy in two ways. First, as a part of normal competitive politics, it distinguishes parties and groups while providing citizens with a sense of belonging. Second, it can be usefully disruptive in challenging norms that are not democratic, such as social injustice and racial hierarchies. The key is managing polarization to prevent it from deepening to its more dangerous forms.

Pernicious polarization generally hurts democracy, but experiencing it can also stimulate positive change by shaking the complacency that grows out of assumptions of cultural or institutional exceptionalism. Finally, recognizing the negative consequences of pernicious polarization can prompt a society to find creative solutions to the underlying deficiencies of representation and socioeconomic inclusion that gave rise to polarizing politics in the first place.

1 Jennifer McCoy and Murat Somer, eds. "Polarization and
Democracy: A Janus-Faced Relationship with Pernicious
Consequences," special issue, American Behavioral Scientist 
62 (January 2018); McCoy and Somer, eds., "Polarizing Polities: A Global Threat to Democracy," special issue, Annals of the American Academy of Political and Social Science 681(January 2019).

2 Laurence Whitehead, "The Hard Truths of Brexit," Journal of Democracy 31 (April 2020): 81-95.

3 Murat Somer, "Turkey: The Slippery Slope from Reformist to Revolutionary Polarization and Democratic Breakdown," Annals of the American Academy of Political and Social Science 681 (January 2019): 42-61; Péter Krekó and Zsolt Enyedi, "Explaining Eastern Europe: Orbán's Laboratory of Illiberalism," Journal of Democracy 29 (July 2018): 39-51.

4 Bridget Welsh, "Malaysia's Political Polarization: Race, Religion, and Reform," in Thomas Carothers and Andrew O'Donohue, eds., Polarization in South and Southeast Asia: Old Divisions, New Dangers (Washington, D.C.: Carnegie Endowment for International Peace, 2020), 41-52.

5 Prajak Kongkirati, "From Illiberal Democracy to Military Authoritarianism: Intra-Elite Struggle and Mass-Based Conflict in Deeply Polarized Thailand," Annals of the American Academy of Political and Social Science 681 (January 2019): 24-40.

6 Umberto Mignozzetti and Matias Spektor, "Brazil: When Political Oligarchies Limit Polarization but Fuel Populism," in Thomas Carothers and Andrew O'Donohue, eds., Democracies Divided: The Global Challenge of Political Polarization (Washington, D.C.: Brookings Institute Press, 2019), 228-254; Alan Abramowitz and Jennifer McCoy, "United States: Racial Resentment, Negative Partisanship, and Polarization in Trump's America," Annals of the 
American Academy of Political and Social Science 681 (January 2019): 137-56.

7 Gi-Wook Shin, "South Korea's Democratic Decay," Journal of Democracy 31 (July 2020): 100-14.

8 Murat Somer, Jennifer McCoy, and Russell Luke, "Pernicious Polarization, Autocratization and Opposition Strategies," Democratization, forthcoming 2021; Anna Lührmann and Staffan I. Lindberg, "A Third Wave of Autocratization Is Here: What Is New About It?" Democratization 26, no. 7 (2019): 1095-113.

9 Murat Somer and Jennifer McCoy, "Déjà Vu? Polarization and Endangered Democracies in the 21st Century," American Behavioral Scientist 62 (January 2018): 3-15.

10 E. E. Schattschneider, The Semi-Sovereign People: A Realist's View of Democracy in America (New York: Holt, Rinehart and Winston, 1960).

11 Corey Robin, "Democracy Is Norm Erosion," Jacobin, January 2018, www.jacobinmag.com/2018/01/democracytrump-authoritarianism-levitsky-zillblatt-norms.

12 Matt Bradley, "Europe's Far-Right Enjoys Backing from Russia's Putin," NBC News, 12 February 2017, www.nbcnews.com/news/world/europe-s-far-right-enjoysbacking-russia-s-putin-n718926; Arch Puddington, Breaking Down Democracy: Goals, Strategies, and Methods of Modern Authoritarianism (Freedom House, 2017), https://freedomhouse.org/report/specialreport/2017/breaking-down-democracy.

13 Somer, "Turkey: The Slippery Slope." 
14 Steven Levitsky and Daniel Ziblatt, How Democracies Die (New York: Crown, 2018); Ezra Klein, Why We're Polarized (New York: Avid Reader Press, 2020).

15 Milan W. Svolik, "Polarization versus Democracy," Journal of Democracy 30 (July 2019): 20-32; Matthew H. Graham and Milan W. Svolik, "Democracy in America? Partisanship, Polarization, and the Robustness of Support for Democracy in the United States," American Political Science Review 114 (May 2020): 392-409.

16 Jennifer McCoy, Gabor Simonovits, and Levente Littvay, "Democratic Hypocrisy: Polarized Citizens Support

Democracy-Eroding Behavior When Their Own Party Is in Power," PsyArXiv Preprint, 29 July 2020, doi:10.31234/osf.io/vrn85.

17 For all respondents, support for the norm-eroding policies was about 6 percentage points higher when their own party was in power than the baseline average of 27 percent when the opposing party was in power, a 22 percent change. We found that Republicans demonstrated about double the amount of democratic hypocrisy that Democrats exhibited, although some of this difference may be due to a non-compliance effect (in other words, some people may have had a hard time envisioning a political context different than the one in which they actually were living).

18 Philip Bump, "By 2040, Two-Thirds of Americans Will Be Represented by 30 Percent of the Senate," Washington Post, 28 November 2017; also see inter alia Jonathan A. Rodden, Why Cities Lose: The Deep Roots of the Urban-Rural Political Divide (New York: Basic Books, 2019). 
19 Klein, Why We're Polarized. Steve Levitsky made the same point at a keynote speech at Cornell University on Nov. 8, 2019.

20 Şebnem Yardımc1-Geyikçi, "Party Institutionalization and Democratic Consolidation," Party Politics 21 (July 2015): 527-38.

21 See www.fairvote.org.

22 McCoy and Somer, eds., "Polarizing Polities"; Somer, McCoy, and Luke, "Pernicious Polarization, Autocratization and Opposition Strategies."

23 Welsh, "Malaysia's Political Polarization;" Miriam Lanskoy and Elspeth Suthers. "Armenia's Velvet Revolution" Journal of Democracy 30, no. 2 (2019): 85-99; Palacios-Valladares, Indira, "Chile's 2019 October Protests and the Student Movement: Eventful Mobilization?". Revista de ciencia politica (Santiago), 40 (2) (2020): 215-234.

24 Dan Slater and Aries A. Arugay, "Polarizing Figures: Executive Power and Institutional Conflict in Asian Democracies," American Behavioral Scientist 62 (January 2018): 92-106.

25 Ronald J. Deibert, "The Road to Digital Unfreedom: Three Painful Truths About Social Media," Journal of Democracy 30 (January 2019): 25-39.

26 Katherine J. Cramer, The Politics of Resentment: Rural Consciousness in Wisconsin and the Rise of Scott Walker (Chicago: University Of Chicago Press, 2016); Arlie Russell Hochschild, Strangers in Their Own Land: Anger and Mourning on the American Right (New York: New Press, 2016). 
27 Mikko Salmela and Christian von Scheve, "Emotional Roots of Right-Wing Political Populism," Social Science Information 56 (December 2017): 567-95.

28 Michael J. Sandel, The Tyranny of Merit: What's Become of the Common Good? (New York: Farrar, Straus and Giroux, 2020).

29 Jacob S. Hacker and Paul Pierson, Let Them Eat Tweets: How the Right Rules in an Age of Extreme Inequality (New York: Liveright, 2020). 